\title{
Assessment of the Marine Ecotoxic State in the Moroccan Coastal Area Anza-Taghazout following the Installation of Two Wastewater Treatment Plants: A Multibiomarker Study using Mytilus Galloprovincialis
}

YOUSSEF EL MOURABIT ( $\nabla$ youssef.elmourabit@edu.uiz.ac.ma )

Ibn Zohr University Faculty of Science Agadir: Universite lbn Zohr Faculte des Sciences Agadir https://orcid.org/0000-0001-9504-0619

\section{Mustapha Agnaou}

Ibn Zohr University: Universite Ibn Zohr

\section{Aicha Ait Alla}

Ibn Zohr University Faculty of Science Agadir: Universite Ibn Zohr Faculte des Sciences Agadir Abdellatif Moukrim

Abdelmalek Essaadi University: Universite Abdelmalek Essaadi

\section{Research Article}

Keywords: Multi-biomarker, Mytilus galloprovincialis, Anza-Taghazout coasts, Integrated Biomarker Response index, Environmental quality, Pollution.

Posted Date: June 3rd, 2021

DOl: https://doi.org/10.21203/rs.3.rs-485293/v1

License: (c) (1) This work is licensed under a Creative Commons Attribution 4.0 International License. Read Full License

Version of Record: A version of this preprint was published at Environmental Science and Pollution Research on September 21st, 2021. See the published version at https://doi.org/10.1007/s11356-02116046-z. 


\section{Abstract}

The aim of the present study is the first to evaluate the ecotoxic state of the marine environment in AnzaTaghazout coasts (Morocco) after installation of two Wastewater Treatment Plants using a natural population of marine bivalves M. galloprovincialis. These coasts are exposed to many discharges generating, thus, different sources of pollutants. These pollutants can modulate the physiological responses of marine bivalves to environmental stress. In this context, a multi-biomarker approach consisting of a battery of biomarkers evaluation was used to assess the response of these species to stress. In the whole soft tissues of $M$. galloprovincialis, four biomarkers were evaluated: Acetylcholinesterase (AChE), Glutathione S-transferase (GST), Catalase (Cat) and malondialdehyde activity (MDA). In parallel, physico-chemical parameters were measured in the marine water of AnzaTaghazout within three selected sites: $\mathrm{S}_{1}$ considered as 'hotspot' located at Anza city; $\mathrm{S}_{2}$ located near of Aourir city and the third site, $S_{3}$ 'reference' located in Imouran beach. Our results showed that activities of both Gluthation-S-Transferase and Catalase were higher in M. galloprovincialis collected from site $\mathrm{S}_{1}$, but high values of Malondialdehyde and Acetylcholinesterase activities were observed successively at $S_{3}$ and $\mathrm{S}_{2}$. Application of Integrated Biomarker Response index (IBR) was suitable for classifying the stress response in the M. galloprovincialis but did not allow to evaluate the level of the xenobiotic exposure in the studied sites. The statistical results did not show any significant differences between the three studied sites and therefore $S_{1}$ has recently become clean due to the installation of two wastewater treatment plants.

\section{Introduction}

In the last years, several studies were interested on the biomarker's activities in sentinel species as important tools to assess environmental quality of the coastal areas in the world. The use of biomarkers as molecular and cellular responses is the best approach for environmental biomonitoring and biomarkers represent the first signals and early index of environmental pollution (Livingstone et al. 1997). Many toxic chemicals effects were evaluated at different levels of biological organization in marine organisms by using a large number of biomarkers (Rank et al. 2007; Viarengo et al. 2007). Thus, biomarkers as quantitative measure of changes in biochemical, physiological or behavioural structure occurring an organism is an appropriate response to xenobiotic exposure such as metallic, organometallic and organic pollutants. Those measures in different parts of cells (tissues, organs or body fluids) provide an earliest warning signal of biological effect which precede sub-cellular or biochemical responses that occur at an organism or population level (Schettino et al. 2012; Hutchinson et al. 2013).

Since 2016, there has been a good ecological action in maritime coasts of Anza-Taghazout in the south coasts of Morocco. Indeed, these coasts suffered from pollution situation for many years. Two wastewater treatment plants (WWTPs) were installed; one located in Anza - city and the second one in Aourir - city. WWTP of Anza treat wastewater of industrial area of Anza, harbor of Agadir and domestic wastewater of Anza city. While, WWTP of Aourir treat wastewater of two cities; Aourir and Tamraght. 
Maritime coasts of Anza-Taghazout, located north of Agadir and which plays a highly important socioeconomic role in Sous Massa region (Morocco), has an important income from maritime fishing and tourist activities. However, it represents polluted habitat due to exposure to toxic liquid effluents of different origins. It contains urban and industrial centers and more sources of anthropogenic pollution (Moukrim et al. 2000). Discharges of industrial wastewater have resulted in high concentrations of trace metals in the shellfish including Cadmium (Cd), Mercury $(\mathrm{Hg})$, Copper $(\mathrm{Cu})$, Zinc $(\mathrm{Zn})$ and Plomb $(\mathrm{Pb})$ in the Bay of Agadir (Moukrim et al. 2000; Banaoui et al. 2004) knowing that industrial and urban wastewaters generated a reel pollution and a present threat to marine ecosystems (Halpern et al. 2008). In addition, many studies identified bacterial pollution in seawater of industrial zone of Anza and Agadir beaches (Mimouni et al. 2002; Chaouay et al. 2014, El Mourabit et al. 2020). Pesticides used in agriculture in neighbouring farms were found also in Anza Beach and Oued Souss estuary located near of Agadir beach (Agnaou et al. 2014, 2018).

All of these pollutants could be the origin of stress situation of marine organisms. This stress is due to environmental conditions and xenobiotic exposure. Stress factors, both natural and anthropogenic, may be a cause of physiological and structural alteration at many levels of the marine organisms. Our previous studies have indeed demonstrated contamination of Agadir coastal by various pollutants using biomarkers (Banaoui et al. 2004; Ait Alla et al. 2006; El Azzaoui et al. 2019). Use of a battery of biomarkers allows an integrated assessment of effects at chemical, cellular, sub-cellular, tissues and whole organism levels due to the dynamic equilibrium of the marine environment.

To closely monitor the impact of installation of the two WWTPs onto the beach's health of maritime coasts of Anza-Taghazout, mussels of Mytilus galloprovincialis can be used as a pollution indicator or bio-accumulator due to its large ecological advantages. In general, bivalves are a good bioindicators for pollution biomonitoring particularly the Mytilus spp. (Taleb et al. 2009). Mytilus spp. accumulate waterborne pollutants during filter feeding of water (Beyer et al. 2017) and they have an efficient detection of many pollutants in water systems Reichwaldt and Ghadouani (2016). Also, they are characterizing by a large geographical distribution, resistance to many contaminants, long life-cycle, easy to capture and to maintain under laboratory-controlled conditions, all of these properties give to these organisms to be a good standard choice for ecotoxicological testing during bioaccumulation monitoring process of many compounds (Teixeira et al. 2017b).

Biomarkers are classified according to events triggered by battery of biomarkers of exposure, effects or sensitivities (Lagadic et al. 1997). Recently, a study involving the determination of a battery of biomarkers in Mytilus galloprovincialis to assess environmental quality showed that the selected battery of biomarkers responded efficiently to the environmental changes and allowed an environmental assessment between seasons and sites (Cravo et al. 2009). Battery of selected biomarkers in our work included four biomarkers which are Acetylcholinesterase (AChE, biomarker of neurotoxicity), glutathione S-transferase (GST, biomarker of detoxification), Catalase activities and malondialdehyde levels (CAT and MDA; biomarkers of oxidative stress and lipid peroxidation). 
AChE has been used as a biomarker in several organisms such as mussels (Doran et al. 2001) due to its sensitivity to many contaminants such as organophosphorus or carbamate compound contamination. These contaminants apply inhibition effect onto AChE activity in mussels. This inhibition is directly linked with the mechanisms of toxic action of anticholinesterase compounds Rodriguez-Fuentes and GoldBouchot (2004) and has been used as an effect biomarker after exposure to pesticides and to certain metals (e.i. lead and mercury) Bocquené and Galgani (1991). Recently, AChE has been identified as a suitable biomarker for incorporation into the OSPAR Coordinated Environmental Monitoring Program (CEMP) (SGIMC, I. 2011).

In addition, GST has been recently identified as a suitable biomarker for monitoring chemical pollution in highly productive marine coastal ecosystems (Vidal-Linãn et al. 2010) and has been widely used as a biomarker of exposure to PAHs, PCBs and trace metals in invertebrates' organisms (Funes et al. 2006). GST are involved in the conjugation and detoxification of organic compounds (Phase II detoxification), which also play a protective role against oxidative stress by catalyzing a selenium independent glutathione peroxidase activity (Sheehan et al. 2001), and which catalyze the conjugation of the reduced form of glutathione (GSH) with xenobiotics that can then be detoxified (Blanchette et al. 2007).

Catalase is an oxidoreductase enzyme present in prokaryotes and eukaryotes cells (Kashiwagi et al. 1997), especially in invertebrates with high activity (Regoli et al. 2002) and which is involved in catalytic conversion of two harmful molecules of hydrogen peroxide $\left(\mathrm{H}_{2} \mathrm{O}_{2}\right)$ into two molecules of water $\left(\mathrm{H}_{2} \mathrm{O}\right)$, and one of oxygen $\left(\mathrm{O}_{2}\right)$ (Gonçalves-Soares et al. 2012). Indeed, molecular oxygen is used naturally in aerobic processes or in oxidative stress occasions which induce catalase activity to be overexpressed to reduce the excess of formed oxygen peroxide (Oruc et al. 2004). So, this enzyme increase might function as a compensatory tool to face oxidative alterations (Van der Oost et al. 2003).

To measure disturbances caused by excessive reactive oxygen species production in marine organism's cells, MDA has been used as good biomarker of oxidative stress (Almeida et al. 2005). MDA used as marker of oxidation of membrane phospholipids through lipid peroxidation (reaction of oxygen with unsaturated lipids) due to oxidative stress (Alexandrova and Bochev 2005) and it is considered as a second carbonyl degradation products of lipid peroxidation of cell membranes. Additionally, toxicity biomarkers, such as MDA, well-known lipid peroxidation products, have been also proposed to reflect the oxidative status of exposed species (Cossu et al. 2000).

Then, to have a good study of all biomarkers, an IBR index was added in this paper to improve the discriminatory power of the adopted multi-biomarker strategy. This technique is used by many researchers in this field (Beliaeff and Burgeot (2002); Sanchez et al. 2013; Devin et al. 2014). Therefore, the aims of the present study were 1) to measure the following activities of four biomarkers (AChE, GST, CAT and MDA) in M. galloprovicialis mussels, 2) to study multi-biomarker strategy using IBR index and 3) to better comprehend the health state of Anza-Taghazout beaches after the installation of two WWTPs.

\section{Material And Methods}




\section{Study areas}

The mussel M. galloprovincialis was collected monthly during two years of biomonitoring from January 2016 to December 2018 in three sites of Anza-Taghazout marine coasts. The first site called Anza beach $\left(S_{1}\right)$ is located at $10 \mathrm{~km}$ in the north of Agadir city near to Anza WWTP and Agadir harbour. It is characterized many years ago by its alarming pollution state and quality of its seawater was in category D (Mimouni et al, 2002; Chaouay et al, 2014). The second one is Aourir Beach $\left(S_{2}\right)$ which receive a treated discharge of Aourir WWTP and effluents of Aourir river during rainfall periods. It is characterized by surf activity and a moderate touristic activity. The third one is called Imouran Beach $\left(\mathrm{S}_{3}\right)$, and it is characterized by the existence of big touristic activities (camping cars for the rest of tourists, hotel units etc...). It should be noted that the two sites $S_{2}$ and $S_{3}$ are clean in comparison of $S_{1}$ (Table 1 and Fig. 1 ).

Table 1 Description of sampling sites and GPS location.

\begin{tabular}{|llll|}
\hline Beaches & Acronym & Latitude (google map) & Longitude (google map) \\
\hline Anza & $\mathrm{S}_{1}$ & $30^{\circ} 26^{\prime} 59.4^{\prime \prime} \mathrm{N}$ & $9^{\circ} 39^{\prime} 43.4^{\prime \prime} \mathrm{W}$ \\
\hline Aourir & $\mathrm{S}_{2}$ & $30^{\circ} 30^{\prime} 08.3^{\prime \prime} \mathrm{N}$ & $9^{\circ} 40^{\prime} 59.0^{\prime \prime} \mathrm{W}$ \\
\hline Imouran & $\mathrm{S}_{3}$ & $30^{\circ} 30^{\prime} 29.2^{\prime \prime} \mathrm{N}$ & $9^{\circ} 41^{\prime} 16.0^{\prime \prime} \mathrm{W}$ \\
\hline
\end{tabular}

\section{Animal sampling}

In this work, one specie of bivalves is used: Mytilus galloprovincialis. Each sample consisted of a pool of 12 mussel's specimens within the same size for each month to create homogenous group (864 specimens during two cycles). Collection was performed at low tide by hands from littoral sediments in the intertidal zone, packed immediately in seawater in plastic bottle, and stored at $4^{\circ} \mathrm{C}$ in ice-cold during transport to the laboratory. Once in the laboratory, the animals were kept at $-80^{\circ} \mathrm{C}$ until day of analysis.

\section{Environmental parameters}

During our studies, many environmental parameters were monitored monthly such as temperature $(T)$, salinity (S), pH, dissolved oxygen (DO) and electrical conductivity (EC) in three sites during two cycles 2017 and 2018. Environmental parameters were measured on site using a portable multiparameter Orion Star $^{\text {TM }}$ A329 Thermo SCIENTIFIC $\circledast$.

\section{Tissue preparation (fraction $\mathbf{S}_{9}$ )}

The soft tissues are taken after thawing the mussels stored at $-80^{\circ} \mathrm{C}$ using a solid scalpel and then dried on absorbent paper to remove excess water. The weight of the entirety tissue mass is taken using a precision scale (0.001). Then, these soft tissues are immersed in $100 \mathrm{mM}$ of Tris buffer at pH 7.4 (Tris [hydroxymethyl] aminomethane) in an ice bath $\left(4^{\circ} \mathrm{C}\right)$, with ratio of $3 \mathrm{~mL}$ of Tris solution per 1 gram of 
fresh tissue and immediately homogenized with an Ultra-Turrax (at $5000 \mathrm{rpm}$ ). Then, an aliquot of the homogenate obtained was centrifuged at $9000 \mathrm{~g}$ for 30 minutes and at $4^{\circ} \mathrm{C}$ in a centrifuge (Sigma 6$16 \mathrm{KR}$ ) to separate the soluble and insoluble compounds. The supernatant obtained at $9000 \mathrm{~g}$ constitutes the post-mitochondrial fraction or $\mathrm{S}_{9}$ which is either directly used or stored at - $80^{\circ} \mathrm{C}$ in Eppendorf tubes labelled until the biomarker assays. Biomarkers were measured by using a spectrophotometer.

\section{Biomarker measurements}

GST, catalase and acetylcholinesterase activities and MDA levels were measured according to the methods of (Habig et al. 1974, Aebi 1983, Ellman et al. 1961; Sunderman et al. 1985) respectively. Total proteins present in the $S_{9}$ fraction were determined according to the method of Lowry et al. (1951), with bovine serum albumin as a reference.

\section{Integrated Biomarker Response}

To combine all of the measured biomarker data into an integrative index, our results were analyzed using IBR methodologies Beliaeff and Burgeot (2002). These two authors have established a simple method summarizing biomarker responses that simplify the interpretation in biomonitoring programs. However, adopting this more recent development of the IBR procedure, the results are the mean of the possible values obtained by permutation of the biomarker data in the mathematical calculation represented by Radar graph (Devin et al. 2014).

\section{Statistical analysis}

All graphs of the present paper were prepared in Microsoft corporation $®$ Excel 2016. The activities of biomarkers were expressed as average \pm standard deviation (SD). Study of Analysis of variance (ANOVA) and Tukey's test $(P<0.05)$ were performed using the StatSoft, Inc. (2014). STATISTICA (data analysis software system, version 12. www.statsoft.com). IBR stress index of all biomarker data (AChE, CAT, GST and MDA) was performed by using original method of Beliaeff and Burgeot (2002) ameliorated by Sanchez et al. (2013).

\section{Results}

\section{Environmental results}

Concentration of five environmental parameters are shown in Table 2. In the three sites studied, values of $\mathrm{pH}$ is ranged from $8.10 \pm 0.19$ in $S_{1}$ to $8.15 \pm 0.14$ in $S_{2}$, temperature from $19.69 \pm 2.68\left(C^{\circ}\right)$ in $S_{3}$ to 20.24 $\pm 2.76\left(\mathrm{C}^{\circ}\right)$ in $\mathrm{S}_{1}$, electrical conductivity from $54.73 \pm 2.04(\mu \mathrm{S} / \mathrm{cm})$ in $\mathrm{S}_{1}$ to $55.45 \pm 1.56(\mu \mathrm{S} / \mathrm{cm})$ in $\mathrm{S}_{3}$, Salinity from $36.09 \pm 1.00(\mathrm{mg} / \mathrm{L})$ in $\mathrm{S}_{1}$ to $36.27 \pm 0.96(\mathrm{mg} / \mathrm{L})$ in $\mathrm{S}_{3}$ and values of $\mathrm{DO}_{2}$ range from $7.89 \pm$ $0.78(\mathrm{mg} / \mathrm{L})$ in $\mathrm{S}_{1}$ to $8.09 \pm 0.92(\mathrm{mg} / \mathrm{L})$ in $\mathrm{S}_{2}$. Environmental results that we have found, follow the climatic conditions. 
Table 2

Mean $\pm \mathrm{SD}$, minimum and maximum of $\mathrm{pH}$, temperature, $\mathrm{EC}$, salinity and values at the three sites. (Mean $\pm \mathrm{SD}(\min ; \max ))$

\begin{tabular}{|llllll|}
\hline Site & $\mathrm{pH}$ & $\mathrm{T}\left(\mathrm{C}^{\circ}\right)$ & $\mathrm{EC}(\mu \mathrm{S} / \mathrm{cm})$ & $\mathrm{Sal}(\mathrm{mg} / \mathrm{L})$ & $\mathrm{DO}_{2}(\mathrm{mg} / \mathrm{L})$ \\
\hline $\mathrm{S}_{1}$ & $8.10 \pm 0.19$ & $20.24 \pm 2.76$ & $54.73 \pm 2.04$ & $36.09 \pm 1.00$ & $7.89 \pm 0.78$ \\
& $(7.2 ; 8.54)$ & $(14.6 ; 27.6)$ & $(46.28 ; 58.69)$ & $(30.02 ; 37,53)$ & $(6.21 ; 10.55)$ \\
$\mathrm{S}_{2}$ & $8.15 \pm 0.14$ & $19.91 \pm 2.99$ & $55,09 \pm 2.14$ & $36.12 \pm 1.09$ & $8.09 \pm 0.92$ \\
& $(7.38 ; 8.43)$ & $(14 ; 29.2)$ & $(46.6 ; 58.82)$ & $(30.02 ; 37.67)$ & $(6.11 ; 10.53)$ \\
$\mathrm{S}_{3}$ & $8.14 \pm 0.14$ & $19.69 \pm 2.68$ & $55.45 \pm 1.56$ & $36.27 \pm 0.96$ & $7.91 \pm 0.85$ \\
& $(7.19 ; 8.4)$ & $(14 ; 26.2)$ & $(50.1 ; 58.69)$ & $(30.52 ; 37.72)$ & $(5.98 ; 10.25)$ \\
\hline
\end{tabular}

\section{Biomarkers Results}

In our study, the dataset formed by four biomarkers was monthly registered between January 2017 and December 2018 during 24 months. Six pools (two whole soft tissues each) of mussels were used. The results of spatiotemporal variation and results of ANOVA Tukey HSD test $(p<0.05)$ at three studied sites are shown in Fig. 2. During the first cycle, CAT concentrations ranged from minimum value of $3.34 \pm 1.43$ $\mu$ mole. $\mathrm{min}^{-1} . \mathrm{mg}^{-1}$ proteins registered at July 2017 in $\mathrm{S}_{2}$ to a maximum value of $234.80 \pm 42.37$ $\mu$ mole. $\mathrm{min}^{-1}$. $\mathrm{mg}^{-1}$ proteins at February 2017 in $\mathrm{S}_{3}$ (Fig. 2a). While, CAT activity in 2018 ranged from minimum values registered in July 2018 in $S_{3}$ with $2.50 \pm 0.82 \mu$ mole. $\mathrm{min}^{-1} . \mathrm{mg}^{-1}$ proteins to high value $97.11 \pm 1.49 \mu$ mole. $\mathrm{min}^{-1} . \mathrm{mg}^{-1}$ proteins at October 2018 in $\mathrm{S}_{1}$. Measured activities of CAT in mussel show a high significant difference between the three studied sites during two cycles except July 2017, September 2017, November 2017 and December 2017 ( $p$ >0.05).

In addition, GST activity presented in Fig. 2b shows, that all months except January 2017, December 2017 and December 2018, show a high significant difference between the three studied sites $(p<0.05)$.

During the first cycle, GST concentrations ranged from minimum value of $4.98 \pm 2.54 \mu$ mole. $\mathrm{min}^{-1} . \mathrm{mg}^{-1}$ proteins registered at August 2017 in $S_{1}$ to a maximum value of $47.95 \pm 1.86 \mu$ mole. $\mathrm{min}^{-1} . \mathrm{mg}^{-1}$ proteins at March 2017. Whereas in 2018, GST concentrations ranged from minimum values registered in May 2018 in $\mathrm{S}_{2}$ with $17.11 \pm 2.31 \mu$ mole. $\mathrm{min}^{-1} . \mathrm{mg}^{-1}$ proteins to high value $71.07 \pm 5.87 \mu$ mole. $\mathrm{min}^{-1} . \mathrm{mg}^{-1}$ proteins in November 2018 in $\mathrm{S}_{1}$.

Spatiotemporal variations of MDA (Fig. 2c) show that the higher activity in the three studied sites during 2017 was registered in February in $S_{3}\left(106.87 \pm 4.32 \mu\right.$ mole. $\mathrm{min}^{-1} . \mathrm{mg}^{-1}$ proteins) and the low activity was recorded in July in $S_{2}\left(1 \pm 0.22 \mu\right.$ mole. $\mathrm{min}^{-1} . \mathrm{mg}^{-1}$ proteins). In 2018 cycle, the low activity $(2.16 \pm$ $0.48 \mu$ mole $\cdot \mathrm{min}^{-1} . \mathrm{mg}^{-1}$ proteins) was registered in January in $\mathrm{S}_{3}$ against high activity $(67.04 \pm 18.42$ 
$\mu$ mole. $\mathrm{min}^{-1} . \mathrm{mg}^{-1}$ proteins) recorded in October in $\mathrm{S}_{1}$. Study of significance between sites shows a high significant difference during two cycles except November 2017, May 2018 and December 2018 ( $p>0.05)$.

AChE activity (Fig. 2d) oscillated from $0.95 \pm 0.32$ nmole. $\mathrm{min}^{-1} \cdot \mathrm{mg}^{-1}$ proteins in November in $\mathrm{S}_{1}$ to 16.54 \pm 1.13 nmole. $\mathrm{min}^{-1} . \mathrm{mg}^{-1}$ proteins in April also in $\mathrm{S}_{1}$ during 2017 and from $1.17 \pm 0.32 \mathrm{nmole} \cdot \mathrm{min}^{-1} . \mathrm{mg}^{-}$ 1 proteins in January in $S_{3}$ to $17.69 \pm 4.59$ nmole. $\mathrm{min}^{-1} \cdot \mathrm{mg}^{-1}$ proteins in September in $\mathrm{S}_{3}$ during 2018 cycle. No difference was observed between sites in August, September, October 2017 and June, July, October 2018 contrary to other months.

Results of study of the difference between two cycles 2017 and 2018 in the three studied sites is shown in Fig .3. We observed an excessive induction and a high significant difference of GST activity of means of three sites in 2018 compared with 2017 cycle (Fig. 3a). In contrast, no difference was observed between two cycles concerning catalase activity (Fig. 3b). Regarding MDA activities, no difference was observed in both $S_{2}$ and $S_{3}$, whilst $S_{1}$ has a high significant difference increased from $8.65 \pm 1.51 \mu$ mole. $\mathrm{min}^{-1} . \mathrm{mg}^{-1}$ proteins in 2017 to $20.73 \pm 1.51 \mu$ mole. $\mathrm{min}^{-1} \mathrm{mg}^{-1}$ proteins in 2018 (Fig. 3c). AChE activities, don't show any difference among two cycles both in $S_{1}$ and $S_{2}$, whilst $S_{3}$ show a high significant inhibition in AChE activity during 2017 with $4.01 \pm 0.47$ nmole. $\mathrm{min}^{-1} . \mathrm{mg}^{-1}$ proteins compared to 2018 with $8.58 \pm 0.47$ nmole. $\mathrm{min}^{-1} . \mathrm{mg}^{-1}$ proteins (Fig. $3 \mathrm{~d}$ ). During the entire period of our study, the accumulation rate of the four biomarkers does not present a significant difference between mussels of the three studied sites $(p>0,05)$ (Table 3$)$.

Table 3

ANOVA and Tukey HSD test of biomarkers results between sites (Mean \pm Std.Err).

\begin{tabular}{|llllll|}
\hline Biomarkers & $\mathbf{S}_{\mathbf{1}}$ & $\mathrm{S}_{\mathbf{2}}$ & $\mathrm{S}_{\mathbf{3}}$ & $\mathrm{F}$ & P-value \\
\hline GST & $30.53 \pm 1.35$ & $28.32 \pm 1.35$ & $26.60 \pm 1.35$ & 2.11 & 0.12 \\
\hline MDA & $14.69 \pm 1.53$ & $16.59 \pm 1.53$ & $19.47 \pm 1.53$ & 2.45 & 0.08 \\
CAT & $37.42 \pm 3.72$ & $35.05 \pm 3.72$ & $35.94 \pm 3.72$ & 0.10 & 0.90 \\
AChE & $5.79 \pm 0.39$ & $6.70 \pm 0.39$ & $6.29 \pm 0.39$ & 1.36 & 0.25 \\
\hline
\end{tabular}

\section{IBR Results}

The contribution of the four biomarkers to the IBR calculation differed according to pollution state of the three studied sites. The most sensitive responses could be visualized in the corresponding radar graph (Fig. 4). The results of IBR (Table 4) indicate a low value registered in $S_{1}(0.00 \pm 0.00)$ and high one in $S_{3}$ 
(5.44 \pm 0.04$)$ during 2017 cycle. Conversely, low IBR was recorded in $S_{3}(0.00 \pm 0.00)$ against high value $(6.78 \pm 0.00)$ registered in $S_{1}$ during 2018 cycle.

Table 4

Summary of IBR values

\begin{tabular}{|llllll|}
\hline Sites & Years & IBR.mean & IBR.sd & IBR.min & IBR.max \\
\hline $\mathrm{S}_{1}$ & $\mathbf{2 0 1 7}$ & 0.00 & 0.00 & 0.00 & 0.00 \\
\cline { 2 - 6 } & $\mathbf{2 0 1 8}$ & 6.78 & 0.00 & 6.78 & 6.79 \\
\hline $\mathrm{S}_{2}$ & $\mathbf{2 0 1 7}$ & 2.12 & 0.40 & 1.68 & 2.46 \\
\cline { 2 - 6 } & $\mathbf{2 0 1 8}$ & 0.13 & 0.05 & 0.09 & 0.18 \\
\hline $\mathrm{S}_{3}$ & $\mathbf{2 0 1 7}$ & 5.44 & 0.04 & 5.40 & 5.46 \\
& $\mathbf{2 0 1 8}$ & 0.00 & 0.00 & 0.00 & 0.00 \\
\hline
\end{tabular}

\section{Discussion}

The current study was carried out to evaluate effect of WWTPs installed on maritime coasts of AnzaTaghazout ecosystem since 2016. It is considered as the first ecotoxicological approach in this region to monitor all the effects related to WWTP installed on marine ecosystem life, using Mytilus galloprovincialis as sentinel species.

Abiotic factors may be a source of influence of biomarker activities. Many studies demonstrated the relationship between abiotic factors (Temperature, salinity, $\mathrm{pH}$, oxygenation, water-type and substrate) and modification of biomarkers expressions (Vidal et al. 2002; Pfeifer et al. 2005). In addition, salinity influence considerably biochemical response of Crassostrea angulate oyster exposed to Arsenic (Moreira et al. 2016). Impact of Arsenic in the embryo-larval development of oysters are altered by changing in salinity and temperature (Moreira et al. 2018). Thus, changes of environmental parameters can heavily influence the enzyme activity of the biomarker (Whyte et al. 2000).

Regarding biomarkers activities shown in Fig. 2 and Fig. 3, biomarkers assessed in three representative sites in the present paper show a seasonal variability. Invertebrates use CAT as an enzyme of antioxidative defence and protection (Regoli et al. 2002). High levels of CAT registered in our studies may be related to an excess of $\mathrm{H}_{2} \mathrm{O}_{2}$ formed after using $\mathrm{O}_{2}$ in aerobic process or oxidative stress occasions (Oruc et al. 2004). Reactive oxygen species (ROS) such as $\mathrm{H}_{2} \mathrm{O}_{2}$ were eliminated by CAT which convert two molecules of $\mathrm{H}_{2} \mathrm{O}_{2}$ into two molecules of $\mathrm{H}_{2} \mathrm{O}$ and one of $\mathrm{O}_{2}$ (Gonçalves-Soares et al. 2012). ROS can be very dangerous for constituents of cells and provoke damage of DNA (Frenzilli et al. 2001), lipid peroxidation (Viarengo 1989) and lysosomal alteration (Winston et al. 1996). The rise of CAT activity may suggest that M. galloprovincialis were subjected to oxidative stress, making it possible to conclude that is in agreement with work of Vidal-Linan et al. (2010) in polluted zone. Previous studies have shown that 
Mytilus.sp presents an induction of CAT activity in response to organic pollution (Porte et al. 1991), trace metals (Duarte et al. 2011), polycyclic aromatic hydrocarbons (Orbea et al. 2006), chemicals compound present in domestic sewage discharge (Saenz et al. 2010), domestic wastewater and agriculture discharge (Abbassi et al. 2015). However, a decrease of CAT activity should not be considered as a signal of a good health state of the environment, but it can be also an index of the difficulties that have organisms in defending against oxidative stress (Regoli et al. 1995). In fact, decrease of CAT activity may be the results of exposure during long time to oxidative stressors. According to several studies which demonstrated that the antioxidant defence can be invaded due to prolonged periods of exposure to contaminants (Lowe and Fossato 2000; Stohs et al. 2000; Duarte et al. 2011).

Concerning AChE activity in Fig. 2d, it shows a seasonal variability as demonstrated by Taleb et al. (2007) and Elazzaoui et al. (2019). It must be recalled that synaptic transmission of nerve impulses requires the contribution of AChE enzyme and is inhibited by neurotoxic compounds like organophosphate and carbamate pesticides (Bocquené et al. 1998). Decrease of AChE in our study may be related to temperature conditions (Kirby et al. 2000). Also, both salinity and temperature could modify AChE activity in bivalves (Pfeifer et al. 2005). Many studies have demonstrated that metals inhibit unselectively AChE activity, while organophosphate and carbamate pesticides inhibit selectively AChE activity, leading to serious physiological deficiency in marine wildlife (Rickwood and Galloway 2004; Tsangaris et al. 2010). In addition, variation in AChE activity in mussels may be related to differences in sex, age, length, weight, or physiological conditions (Fairbrother et al. 1989).

Besides this, GST activities in Mytilus galloprovincialis present seasonal variations in the three studied sites. It is worthwhile to note that the highest enzyme induction found in our studies is explained by many factors. High induction of the GST activity reflects a stress state due to contamination by organic compost such as HAPs (Trisciani et al. 2012). In addition, dioxins may also induce GST activity (Van der Oost et al. 2003). This induction enters into phase II reactions biotransformation of chemical compounds (Sheehan et al. 1999) specially in digestive gland of mussels which is characterized by abundance of GST activity and which paly highest role in conjugation detoxifying metabolism (Canesi et al. 2007). In an industrialized area for example, active monitoring has demonstrated that mussels from the most polluted sites show a significant higher GST and GPx activities compared to the control site (Vidal-Linan et al. 2014). Drug cetirizine induces a decrease of GST activity in M. galloprovincialis (Coppola et al., 2017). While, trace elements, nanoparticles and a mixture of endocrine disruptor compounds including NP, endocrine disruptor bisphenol-A increase this activity (Canesi et al. 2008; Coppola et al. 2017). It is primordial to be taken in account that, mussels exposed continuously to a weak level of toxicity and which is not high enough to elicit an efficient response may be the origin of a weak response of GST due to acclimatization of mussels to these conditions (Wepener et al. 2008). Variations of temperature can also be the origin of the GST activities in M. galoprovincialis as studies of (Kayaa et al. 1999) have proved that temperatures below $20^{\circ} \mathrm{C}$ and above $35^{\circ} \mathrm{C}$ generated weakest activities of GST while highest activities were found at $30^{\circ} \mathrm{C}$ for the mussels of M. galloprovincialis. Variations of GST activity could be also linked to the mussel's reproduction cycle (Id Halla et al. 1997) and high levels of GST activity may be 
due to restoration of reserves and gametogenesis periods while lower values coincide with spawning periods (Kayaa et al. 1999).

Induction of MDA during winter season months may indicate an oxidative stress situation due to high contamination in bivalves. The MDA content in combination with variations in the activity of the antioxidant enzymes expresses the lipid peroxidation at the cellular membrane phospholipids (Alexandrova and Bochev 2005). It is correlated to the contamination of the aquatic environment by polyaromatic hydrocarbons (HAP) and heavy metals (Labrot et al. 1996; Frouin et al. 2007). Lipid peroxidation is generated in aquatic organisms exposed to high concentrations of toxic substances, including HAPs (Downs et al. 2002). Existence of HAPs in the marine environment is due to atmospheric emissions, water-efficient effluents and surface runoffs (Simpson et al. 1996). Indeed, MDA is carbonyl degradation products of lipid peroxidation of cell membranes which reflect the oxidative status of exposed species after oxidative stress (Cossu et al. 2000; Blaise et al. 2002). The concentration of MDA has been largely used as a biomarker of disturbances caused by excessive production of ROS in the cells of marine organisms (Almeida et al. 2005). Seasonal variability of MDA concentration during our studies may also translate the relationship between reproductive cycle and oxidative stress in bivalves (Wilhelm Filho et al. 2001).

IBR method is used to estimate amplitude of contamination. Four measured biomarker data were combined into an integrative index namely IBR index (Beliaeff and Burgeot 2002). Mussels exposed to high concentrations of pollutants during our period of survey translate high IBR value observed in Radar graph both in $S_{3}$ in 2017 and in $S_{1}$ in 2018. Conversely to low IBR value registered in $S_{1}$ in 2017 and in $S_{3}$ in 2018 which explain exposing of mussels to low concentrations of contaminants. For example, studies of (Peric and Buric 2019) demonstrate that exposure of mussels Mytilus galloprovincialis to $5 \mathrm{mg} / \mathrm{L}$ of organophosphorous pesticide chlorpyrifos resulted in low IBR value, conversely to high IBR value registered at $15 \mathrm{mg} / \mathrm{L}$ of metal copper. In addition, (Bocquené et al. 2004) used IBR index to combine AChE, GST, CAT activities and MDA concentrations, on the common mussel Mytilus edulis in the coast of Brittany (France) and they found that IBR index was strongly related to MDA levels (Bocquené et al. 2004). Broeg and Lehtonen 2006, measuring IBR in eelpout (Zoarces viviparous) and blue mussel (Mytilus sp.) populations of the Baltic Sea, reported good accordance between IBR and tissue levels of organochlorine compounds and they have concluded that IBR becomes more robust when the number of biomarkers increases. Damiens et al. 2007, found good agreement between IBR values and copper, PCB concentrations in transplanted mussels but not with PAHs concentrations.

However, IBR is not suitable for giving an indication of the level of stress in the mussels; this IBR recognizes variations in the studied biomarkers, but not their biological meaning (Bouhallaoui et al. 2017). Beliaeff and Burgeot (2002), also concluded that the selection of an appropriate battery of biomarkers allow information to be summarized in the form of a multivariate data and can avoid falsenegative responses obtained with a single biomarker. Interpretation of IBR data must be done carefully considering possible mutual interference of mixture components, often asynchronous and complex biomarkers responses and magnitude of response of each biomarker (Quintaneiro et al. 2015). 


\section{Conclusion}

In conclusion, this ecotoxic assessment performed in Anza-Taghazout coasts has enabled us to confirm the ecological restoration of the health stat of Anza beach. The actual health state of $S_{1}$ may be due to installation of two WWTPs in the two cities of Anza and Aourir.

Furthermore, multibiomarker approach assessment has revealed a seasonal variability of the four biomarkers measured in soft tissues of sentinel species $M$. galloprovincialis at the three sites of interest. In addition to that, IBR approach allows us to good visualization of biological effect of contaminants on Mussels. This combination of four biomarkers data allows obtaining a compact means of representing data.

The lack of significant differences between the three studied sites is a good indicator that $\mathrm{S}_{1}$ which had been qualified many years ago as the most polluted area within the region of Agadir coastline, has recently become clean.

To sum up, these ecotoxicological approaches with biomonitoring studies on site give us an idea about area health state after installation of the two WWTPs in Anza and Aourir and similar studies like ours could be a reference of positive impact of WWTP onto health state of maritime coasts.

\section{Declarations}

\section{Ethics approval and consent to participate}

"Not applicable" in this section,

\section{Consent for publication}

I give my consent for the publication of details of this work in the above Journal and article.

\section{Availability of data and materials}

The data that support the findings of this study are available from the corresponding author, [Youssef EL Mourabit], upon reasonable request.

\section{Declaration of competing interest}

All the authors of the present article declare to have no actual or potential conflict of interest including any financial, personal or other relationships with other people or organizations. The following article has not been published previously and that it is not under consideration for publication elsewhere, that its publication is approved by all authors and tacitly or explicitly by the responsible authorities where the work was carried out, and that, if accepted, it will not be published elsewhere in the same form, in English or in any other language, without the written consent of the copyright-holder. 


\section{Funding}

No funding was received to assist with the preparation of this manuscript

\section{Author contributions}

All the authors declare to have participated in this study, with the following participation: Youssef EL MOURABIT, Abdellatif MOUKRIM and Aicha AIT ALLA: Experimental design and Methodology, Youssef EL MOURABIT and Mustapha AGNAOU: Experiment assays and analysis, all authors: Writing - review and editing.

\section{Acknowledgments}

Our gratitude is expressed to Prof. Saïd EL Madidi for his statistical advices and Prof. Youssef El Ouidani for grammatical language correction.

\section{References}

1. Abbassi, M., Banaoui, A., Kaaya, A., Elkhou, A., Nadir, M., Lefrere, L., 2015. Biomarker approach to the assessment of the health status of Moroccan marine ecosystems: preliminary study in Sidi Ifni coast (South of Morocco). Journal of Materials and Environmental Science, 6(11), 3086-3093.

2. Aebi, H. E., 1983. Catalase. Methods of enzymatic analysis.

3. Agnaou, M., Ait Alla, A., Ouassas, M., Bazzi, L., El Alami, Z., Moukrim, A., 2014. Assessment of organochlorine pesticides contamination of oued souss estuary (South of Morocco): seasonal variability in sediment and a detritivore annelid Neries diversicolor. Journal of Materials and Environmental Science, 5(2), 581-586.

4. Agnaou, M., Nadir, M., Alla, A. A., Bazzi, L., El Alami, Z., Moukrim, A., 2018. The occurrence and spatial distribution of pesticides in sea water of the Agadir bay (South of Morocco). ecosystems, 13, 14.

5. Ait Alla, A., Mouneyrac, C., Durou, C., Moukrim, A., Pellerin, J., 2006. Tolerance and biomarkers as useful tools for assessing environmental quality in the Oued Souss estuary (Bay of Agadir, Morocco). Comparative Biochemistry \& Physiology Part C 143 : 23-29.

https://doi.org/10.1016/j.cbpc.2005.11.015.

6. Alexandrova, M. L., Bochev, P. G., 2005. Oxidative stress during the chronic phase after stroke. Free Radical Biology and Medicine, 39(3), 297-316. https://doi.org/10.1016/j.freeradbiomed.2005.04.017.

7. Almeida, E. A., Bainy, A. C. D., Dafre, A. L., Gomes, O. F., Medeiros, M. H., Di Mascio, P., 2005. Oxidative stress in digestive gland and gill of the brown mussel (Perna perna) exposed to air and resubmersed. Journal of Experimental Marine Biology and Ecology, 318(1), 21-30. https://doi.org/10.1016/j.jembe.2004.12.007.

8. Banaoui, A., Chiffoleau, J. F., Moukrim, A., Burgeot, T., Kaaya, A., Auger, D., Rozuel, E., 2004. Trace metal distribution in the mussel Perna perna along the Moroccan coast. Marine pollution bulletin, 48(3-4), 385-390. doi:10.1016/j.marpolbul.2003.11.007. 
9. Beliaeff, B., Burgeot, T., 2002. Integrated biomarker response: a useful tool for ecological risk assessment. Environmental Toxicology and Chemistry: An International Journal, 21(6), 1316-1322. https://doi.org/10.1016/j.aquatox.2014.01.004.

10. Beyer, J., Green, N. W., Brooks, S., Allan, I. J., Ruus, A., Gomes, T., Bråte I.L.N., Schøyen, M., 2017. Blue mussels (Mytilus edulis spp.) as sentinel organisms in coastal pollution monitoring: a review. Marine environmental research, 130, 338-365. https://doi.org/10.1016/j.marenvres.2017.07.024.

11. Blaise, C., Gagné, F., Pellerin, J., Hansen, P. D., Trottier, S., 2002. Molluscan shellfish biomarker study of the Quebec, Canada, Saguenay Fjord with the soft-shell clam, Mya arenaria. Environmental Toxicology: An International Journal, 17(3), 170-186. https://doi.org/10.1002/tox.10048.

12. Blanchette, B., Feng, X., Singh, B. R., 2007. Marine glutathione S-transferases. Marine biotechnology, 9(5), 513-542. https://doi.org/10.1007/s10126-007-9034-0.

13. Bocquené, G., Carbamates, Galgani, F., 1998. Biological effects of contaminants: cholinesterase inhibition by organophosphate and carbamate compounds (pp. 1-13). Copenhagen, Denmark: International Council for the Exploration of the Sea.

14. Bocquené, G., Chantereau, S., Clérendeau, C., Beausir, E., Ménard, D., Raffin, B., Minier, C., Burgeot, T., Leszkowicz A.P., Narbonne, J. F., 2004. Biological effects of the "Erika" oilspill on the commonmussel (Mytilus edulis). Aquatic Living Resources, 17(3), 309-316. https://doi.org/10.1051/alr:2004033.

15. Bocquené, G., Galgani, F., 1991. L'acétylcholinestérase chez les organismes marins, outil de surveillance des effets des pesticides organophosphorés et carbamates. Oceanis, 17, 439-448. https://doi.org/10.1051/alr:2004033.

16. Bouhallaoui, M., Zbiry, M., Elkhiati, N., Talba, S., Sforzini, S., Viarengo, A., Benhra, A., 2017.Use of biomarkers to evaluate the effects of environmental stressors on Mytilus galloprovincialis sampled along the Moroccan coasts: integrating biological and chemical data. Marine Environmental Research, 130, 60-68. https://doi.org/10.1016/j.marenvres.2017.05.010.

17. Canesi, L., Borghi, C., Ciacci, C., Fabbri, R., Lorusso, L. C., Vergani, L., Marcomini, A., Poiana, G., 2008. Short-term effects of environmentally relevant concentrations of EDC mixtures on Mytilus galloprovincialis digestive gland. Aquatic toxicology, 87(4), 272-279. https://doi.org/10.1016/j.aquatox.2008.02.007.

18. Canesi, L., Borghi, C., Ciacci, C., Fabbri, R., Vergani, L., Gallo, G., 2007. Bisphenol-A alters gene expression and functional parameters in molluscan hepatopancreas. Molecular and cellular endocrinology, 276(1-2), 36-44. https://doi.org/10.1016/j.mce.2007.06.002.

19. Chaouay, A., Bazzi, L., Hilali, M., Alla, A. A., El Mouaden, K., 2014. Study of bacterial contamination of the Bay of Agadir Impact on the resistance of copper's corrosion. J. Mater. Environ. Sci, 5, 2472-2477.

20. Coppola, F., Almeida, Â., Henriques, B., Soares, A. M., Figueira, E., Pereira, E., Freitas, R., 2017. Biochemical impacts of $\mathrm{Hg}$ in Mytilus galloprovincialis under present and predicted warming scenarios. Science of the Total Environment, 601, 1129-1138.

https://doi.org/10.1016/j.scitotenv.2017.05.201. 
21. Cossu, C., Doyotte, A., Babut, M., Exinger, A., Vasseur, P., 2000. Antioxidant biomarkers in freshwater bivalves, Uniotumidus, in response to different contamination profiles of aquatic sediments. Ecotoxicology and Environmental Safety, 45(2), 106-121. https://doi.org/10.1006/eesa.1999.1842.

22. Cravo, A., Lopes, B., Serafim, Â., Barreira, L., Gomes, T., Bebianno, M. J., 2009. A multibiomarker approach in Mytilus galloprovincialis to assess environmental quality. Journal of Environmental Monitoring, 11(9), 1673-1686. https://doi.org/10.1039/B909846A.

23. Damiens, G., Gnassia-Barelli, M., Loquès, F., Roméo, M., Salbert, V., 2007. Integrated biomarker response index as a useful tool for environmental assessment evaluated using transplanted mussels. Chemosphere, 66(3), 574-583. https://doi.org/10.1016/j.chemosphere.2006.05.032.

24. Devin, S., Burgeot, T., Giambérini, L., Minguez, L., Pain-Devin, S., 2014. The integrated biomarker response revisited: optimization to avoid misuse. Environmental Science and Pollution Research, 21(4), 2448-2454. https://doi.org/10.1007/s11356-013-2169-9.

25. Doran, W. J., Cope, W. G., Rada, R. G., Sandheinrich, M. B., 2001. Acetylcholinesterase inhibition in the three-ridge mussel (Amblema plicata) by chlorpyrifos: implications for biomonitoring. Ecotoxicology and Environmental Safety, 49(1), 91-98. https://doi.org/10.1006/eesa.2000.2036.

26. Downs, C. A., Shigenaka, G., Fauth, J. E., Robinson, C. E., Huang, A., 2002. Cellular physiological assessment of bivalves after chronic exposure to spilled Exxon Valdez crude oil using a novel molecular diagnostic biotechnology. Environmental science \& technology, 36(13), 2987-2993. https://doi.org/10.1021/es011433k.

27. Duarte, C. A., Giarratano, E., Amin, O. A., Comoglio, L. I., 2011. Heavy metal concentrations and biomarkers of oxidative stress in native mussels (Mytilus edulis chilensis) from Beagle Channel coast (Tierra del Fuego, Argentina). Marine Pollution Bulletin, 62(8), 1895-1904. https://doi.org/10.1016/j.marpolbul.2011.05.031.

28. EL HAMIDI, F., BANAOUI, A., AZDI, M., KAAYA, A., ZEKHNINI, A., 2003. Utilisation de la réponse de quatre biomarqueurs d'exposition chez les bivalves Perna perna et Donax trunculus pour l'évaluation de la pollution dans la baie d'Agadir (Sud du Maroc). Haliotis (Paris), 32, 51-60.

29. El Mourabit, Y., Ait Alla, A., Bihadassen, B., Moukrim, A., 2020.Impact of the installation of two WWTPs on the microbiological quality of sea water in the Anza-Taghazout coasts (Southwest of Morocco). American Journal of Innovative Research and Applied Sciences. 2020; 11(3): 143-153.

30. Elazzaoui, A., Moukrim, A., Lefrere, L., 2019. A Multibiomarker Approach to Assess the Health State of Coastal Ecosystem Receiving Desalination Plants in Agadir Bay, Morocco. The Scientific World Journal, 2019. https://doi.org/10.1155/2019/5875027.

31. Ellman, G. L., CouO9rtney, K. D., Andres Jr, V., Featherstone, R. M., 1961. A new and rapid colorimetric determination of acetylcholinesterase activity. Biochemical pharmacology, 7(2), 88-95. https://doi.org/10.1016/0006-2952(61)90145-9.

32. Fairbrother, A., Bennett, R. S., Bennett, J. K., 1989. Sequential sampling of plasma cholinesterase in mallards (Anas platyrhynchos) as an indicator of exposure to cholinesterase inhibitors. Environmental Toxicology and Chemistry: An International Journal, 8(2), 117-122. 
33. Frenzilli, G., Nigro, M., Scarcelli, V., Gorbi, S., Regoli, F., 2001. DNA integrity and total oxyradical scavenging capacity in the Mediterranean mussel, Mytilus galloprovincialis: a field study in a highly eutrophicated coastal lagoon. Aquatic Toxicology, 53(1), 19-32. https://doi.org/10.1016/S0166445X(00)00159-4.

34. Frouin, H., Pellerin, J., Fournier, M., Pelletier, E., Richard, P., Pichaud, N., Rouleau, C., Garnerot, F., 2007. Physiological effects of polycyclic aromatic hydrocarbons on soft-shell clam Mya arenaria. Aquatic toxicology, 82(2), 120-134. https://doi.org/10.1016/j.aquatox.2007.02.005.

35. Funes, V., Alhama, J., Navas, J. I., López-Barea, J., Peinado, J., 2006. Ecotoxicological effects of metal pollution in two mollusc species from the Spanish South Atlantic littoral. Environmental Pollution, 139(2), 214-223. https://doi.org/10.1016/j.envpol.2005.05.016.

36. Gonçalves-Soares, D., Zanette, J., Yunes, J. S., Yepiz-Plascencia, G. M., Bainy, A. C., 2012. Expression and activity of glutathione S-transferases and catalase in the shrimp Litopenaeus vannamei inoculated with a toxic Microcystis aeruginosa strain. Marine environmental research, 75, 54-61. https://doi.org/10.1016/j.marenvres.2011.07.007.

37. Habig, W. H., Pabst, M. J., Jakoby, W. B., 1974. Glutathione S-transferases the first enzymatic step in mercapturic acid formation. Journal of biological Chemistry, 249(22), 7130-7139. https://doi.org/10.1016/S0021-9258(19)42083-8.

38. Halpern, B.S., Walbridge, S., Selkoe, K.A., Kappel, C.V., Micheli, F., D'Agrosa, C., Bruno, J.F., Casey, K.S., Ebert, C., Fox, H.E., Fujita, R., Heinemann, D., Lenihan, H.S., Madin, E.M., Perry, M.T., Selig, E.R., Spalding, M., Steneck, R., Watson, R., 2008. A global map of human impact on marine ecosystems. Science 319, 948-952. DOI: 10.1126/science.1149345.

39. Hutchinson, T. H., Lyons, B. P., Thain, J. E., Law, R. J., 2013. Evaluating legacy contaminants and emerging chemicals in marine environments using adverse outcome pathways and biological effects-directed analysis. Marine pollution bulletin, 74(2), 517-525. https://doi.org/10.1016/j.marpolbul.2013.06.012.

40. Hylland, K., Gubbins, M., Robinson, C., Lang, T., Vethaak, A. D., Martinez-Gomez, C., Burgeot, T., Svavarsson, J., Thain, J. E., 2012. Theory and practice of integrated monitoring in marine ecosystems-The ICON programme. Comparative Biochemistry and Physiology Part A. Molecular and Integrative Physiology, 163, S51-S52. https://doi.org/10.1016/j.cbpa.2012.05.152.

41. Idhalla, M., Bouhaimi, A., Zekhnini, A., Narbonne, J. F., Mathieu, M., 1997. Etude du cycle de reproduction de deux espèces de moules Perna perna (Linné, 1758) et Mytilus galloprovincialis Lamarck, 1819 dans la baie d'Agadir (Sud du Maroc). Haliotis (Paris), 26, 51-62.

42. Kaaya, A., Najimi, S., Ribera, D., Narbonne, J. F., Moukrim, A., 1999. Characterization of glutathione Stransferases (GST) activities in Perna perna and Mytilus galloprovincialis used as a biomarker of pollution in the Agadir marine bay (South of Morocco). Bulletin of environmental contamination and toxicology, 62(5), 623-629. https://doi.org/10.1007/s001289900920.

43. Kashiwagi, A., Kashiwagi, K., Takase, M., Hanada, H., Nakamura, M., 1997. Comparison of catalase in diploid and haploid Rana rugosa using heat and chemical inactivation techniques. Comparative 
Biochemistry and Physiology Part B: Biochemistry and Molecular Biology, 118(3), 499-503. https://doi.org/10.1016/S0305-0491(97)00216-2.

44. Labrot, F., Ribera, D., Denis, M. S., Narbonne, J. F., 1996. In vitro and in vivo studies of potential biomarkers of lead and uranium contamination: lipid peroxidation, acetylcholinesterase, catalase and glutathione peroxidase activities in three non-mammalian species. Biomarkers, 1(1), 21-28. https://doi.org/10.3109/13547509609079343.

45. Lagadic, L., Caquet, T., Amiard, J.C., Ramade, F. (Eds.), 1997. Biomarqueurs en Ecotoxicologie. Aspects Fondamentaux. Masson, Paris, 419 pp.

46. Livingstone, D. R., Nasci, C., Solé, M., Da Ros, L., O'Hara, S. C., Peters, L. D., Fossato, V., Wootton, A.N., Goldfarb, P. S., 1997. Apparent induction of a cytochrome P450 with immunochemical similarities to CYP1A in digestive gland of the common mussel (Mytilus galloprovincialis L.) with exposure to 2, 2', 3, 4, 4', 5'-hexachlorobiphenyl and Arochlor 1254. Aquatic toxicology, 38(4), 205-224. https://doi.org/10.1016/S0166-445X(96)00847-8.

47. Lowe, D. M., Fossato, V. U., 2000. The influence of environmental contaminants on lysosomal activity in the digestive cells of mussels (Mytilus galloprovincialis) from the Venice Lagoon. Aquatic Toxicology, 48(2-3), 75-85. https://doi.org/10.1016/S0166-445X(99)00054-5.

48. Mimouni, R., Ait Alla, A., Anajjar, E. A., Finance, C., Moukrim, A., 2002. Impact of wastewater discharges on the microbiological quality of beaches in the Agadir Bay (Morocco). Journal Européen d'Hydrologie (France).

49. Moore, M. N., 1976. Cytochemical demonstration of latency of lysosomal hydrolases in digestive cells of the common mussel, Mytilus edulis, and changes induced by thermal stress. Cell and tissue research, 175(3), 279-287. https://doi.org/10.1007/BF00218706.

50. Moukrim, A., Kaaya, A., Najimi, S., Roméo, M., Gnassia-Barelli, M., Narbonne, J. F., 2000. Assessment of the trace metal levels in two species of mussels from the Agadir Marine Bay, South of Morocco. Bulletin of environmental contamination and toxicology, 65(4), 478-485. https://doi.org/10.1007/s001280000149.

51. Orbea, A., Cajaraville, M. P., 2006. Peroxisome proliferation and antioxidant enzymes in transplanted mussels of four Basque estuaries with different levels of polycyclic aromatic hydrocarbon and polychlorinated biphenyl pollution. Environmental Toxicology and Chemistry: An International Journal, 25(6), 1616-1626. https://doi.org/10.1897/04-520R2.1.

52. Oruc, E. O., Sevgiler, Y., Uner, N., 2004. Tissue-specific oxidative stress responses in fish exposed to 2, 4-D and azinphosmethyl. Comparative Biochemistry and Physiology Part C: Toxicology \& Pharmacology, 137(1), 43-51. https://doi.org/10.1016/j.cca.2003.11.006.

53. Perić, L., Burić, P., 2019. The effect of copper and chlorpyrifos co-exposure on biomarkers in the marine mussel Mytilus galloprovincialis. Chemosphere, 225, 126-134. https://doi.org/10.1016/j.chemosphere.2019.03.003.

54. Pfeifer, S., Schiedek, D., \& Dippner, J. W. (2005). Effect of temperature and salinity on acetylcholinesterase activity, a common pollution biomarker, in Mytilus sp. from the south-western 
Baltic Sea. Journal of experimental marine biology and ecology, 320(1), 93-103. https://doi.org/10.1016/j.jembe.2004.12.020.

55. Porte, C., Sole, M., Albaiges, J., Livingstone, D. R., 1991. Responses of mixed-function oxygenase and antioxidase enzyme system of Mytilus sp. to organic pollution. Comparative biochemistry and physiology. C, Comparative pharmacology and toxicology, 100(1-2), 183. 10.1016/07428413(91)90150-r .

56. Quintaneiro, C., Ranville, J., Nogueira, A. J. A., 2015. Effects of the essential metals copper and zinc in two freshwater detritivores species: Biochemical approach. Ecotoxicology and Environmental Safety, 118, 37-46. https://doi.org/10.1016/j.ecoenv.2015.04.006.

57. Rank, J., Lehtonen, K. K., Strand, J., Laursen, M., 2007. DNA damage, acetylcholinesterase activity and lysosomal stability in native and transplanted mussels (Mytilus edulis) in areas close to coastal chemical dumping sites in Denmark. Aquatic Toxicology, 84(1), 50-61. https://doi.org/10.1016/j.aquatox.2007.05.013.

58. Regoli, F., Gorbi, S., Frenzilli, G., Nigro, M., Corsi, I., Focardi, S., Winston, G. W., 2002. Oxidative stress in ecotoxicology: from the analysis of individual antioxidants to a more integrated approach. Marine Environmental Research, 54(3-5), 419-423. https://doi.org/10.1016/S0141-1136(02)00146-0.

59. Regoli, F., Principato, G., 1995. Glutathione, glutathione-dependent and antioxidant enzymes in mussel, Mytilus galloprovincialis, exposed to metals under field and laboratory conditions: implications for the use of biochemical biomarkers. Aquatic toxicology, 31(2), 143-164. https://doi.org/10.1016/0166-445X(94)00064-W.

60. Reichwaldt, E. S., and Ghadouani, A., 2016. Can mussels be used as sentinel organisms for characterization of pollution in urban water systems?. Hydrology and Earth System Sciences, 20(7), 2679. https://doi.org/10.5194/hess-20-2679-2016.

61. Rickwood, C. J., Galloway, T. S., 2004. Acetylcholinesterase inhibition as a biomarker of adverse effect: a study of Mytilus edulis exposed to the priority pollutant chlorfenvinphos. Aquatic Toxicology, 67(1), 45-56. https://doi.org/10.1016/j.aquatox.2003.11.004.

62. Rodríguez-Fuentes, G., Gold-Bouchot, G., 2004. Characterization of cholinesterase activity from different tissues of Nile tilapia (Oreochromis niloticus). Marine environmental research, 58(2-5), 505509. https://doi.org/10.1016/j.marenvres.2004.03.037.

63. Sáenz, L. A., Seibert, E. L., Zanette, J., Fiedler, H. D., Curtius, A. J., Ferreira, J. F., de Almeida, E.A., Marques, M.R.F., Bainy, A. C. D., 2010. Biochemical biomarkers and metals in Perna perna mussels from mariculture zones of Santa Catarina, Brazil. Ecotoxicology and Environmental Safety, 73(5), 796-804. https://doi.org/10.1016/j.ecoenv.2010.02.015.

64. Sanchez, W., Burgeot, T., Porcher, J. M., 2013. A novel "Integrated Biomarker Response" calculation based on reference deviation concept. Environmental Science and Pollution Research, 20(5), 27212725. https://doi.org/10.1007/s11356-012-1359-1.

65. Schettino, T., Caricato, R., Calisi, A., Giordano, M. E., Lionetto, M. G., 2012. Biomarker approach in marine monitoring and assessment: new insights and perspectives. Open Environmental Sciences, 
6(1). 10.2174/1876325101206010020

66. SGIMC, I., 2011. Report of the study group on integrated monitoring of contaminants and biological effects (SGIMC) 14-18 March, Copenhagen, Denmark. ICES CM.

67. Sheehan, D., MEADE, G., FOLEY, V. M., DOWD, C. A., 2001. Structure, function and evolution of glutathione transferases: implications for classification of non-mammalian members of an ancient enzyme superfamily. Biochemical journal, 360(1), 1-16. https://doi.org/10.1042/bj3600001.

68. Sheehan, D., Power, A., 1999. Effects of seasonality on xenobiotic and antioxidant defence mechanisms of bivalve molluscs. Comparative Biochemistry and Physiology Part C: Pharmacology, Toxicology and Endocrinology, 123(3), 193-199. https://doi.org/10.1016/S0742-8413(99)00033-X.

69. Simpson, C. D., Mosi, A. A., Cullen, W. R., Reimer, K. J., 1996. Composition and distribution of polycyclic aromatic hydrocarbon contamination in surficial marine sediments from Kitimat Harbor, Canada. Science of the total environment, 181(3), 265-278. https://doi.org/10.1016/00489697(95)05026-4.

70. Stohs, S. J., Bagchi, D., Hassoun, E., Bagchi, M., 2000. Oxidative mechanisms in the toxicity of chromium and cadmium ions. Journal of environmental pathology, toxicology and oncology: official organ of the International Society for Environmental Toxicology and Cancer, 19(3), 201-213.

71. Sunderman, F. W., Marzouk, A., Hopfer, S. M., Zaharia, O., Reid, M. C., 1985. Increased lipid peroxidation in tissues of nickel chloride-treated rats. Annals of Clinical \& Laboratory Science, 15(3), 229-236.

72. Taleb, Z. M., Benali, I., Gherras, H., Ykhlef-Allal, A., Bachir-Bouiadjra, B., Amiard, J. C., Boutiba, Z., 2009. Biomonitoring of environmental pollution on the Algerian west coast using caged mussels Mytilus galloprovincialis. Oceanologia, 51(1), 63-84.

73. Taleb, Z. M., Benghali, S., Kaddour, A., Boutiba, Z., 2007. Monitoring the biological effects of pollution on the Algerian west coast using mussels Mytilus galloprovincialis. Oceanologia, 49(4).

74. Teixeira, M., Almeida, A., Calisto, V., Esteves, V., Schneider, R.J., Wrona, F.J., Soares, A., Figueira, E., Freitas, R., 2017b. Toxic effects of the antihistamine cetirizine in mussel Mytilus galloprovincialis. Water Res. 114, 316-326. https://doi.org/10.1016/j.watres.2017.02.032.

75. Trisciani, A., Perra, G., Caruso, T., Focardi, S., Corsi, I., 2012. Phase I and II biotransformation enzymes and polycyclic aromatic hydrocarbons in the Mediterranean mussel (Mytilus galloprovincialis, Lamarck, 1819) collected in front of an oil refinery. Marine environmental research, 79, 29-36. https://doi.org/10.1016/j.marenvres.2012.04.006.

76. Tsangaris, C., Kormas, K., Strogyloudi, E., Hatzianestis, I., Neofitou, C., Andral, B., Galgani, F., 2010. Multiple biomarkers of pollution effects in caged mussels on the Greek coastline. Comparative Biochemistry and Physiology Part C: Toxicology \& Pharmacology, 151(3), 369-378. https://doi.org/10.1016/j.cbpc.2009.12.009.

77. Van der Oost, R., Beyer, J., Vermeulen, N. P., 2003. Fish bioaccumulation and biomarkers in environmental risk assessment: a review. Environmental toxicology and pharmacology, 13(2), 57149. https://doi.org/10.1016/S1382-6689(02)00126-6. 
78. Viarengo, A., Lowe, D., Bolognesi, C., Fabbri, E., Koehler, A., 2007. The use of biomarkers in biomonitoring: a 2-tier approach assessing the level of pollutant induced stress syndrome in sentinel organisms. Comp. Biochem. Physiol., Part C 146, 281-300. https://doi.org/10.1016/j.cbpc.2007.04.011.

79. Viarengo, A., Pertica, M., Canesi, L., Accomando, R., Mancinelli, G., Orunesu, M., 1989. Lipid peroxidation and level of antioxidant compounds (GSH, vitamin $\mathrm{E}$ ) in the digestive glands of mussels of three different age groups exposed to anaerobic and aerobic conditions. Marine environmental research, 28(1-4), 291-295. https://doi.org/10.1016/0141-1136(89)90246-8.

80. Vidal, M. L., Bassères, A., \& Narbonne, J. F. (2002). Influence of temperature, pH, oxygenation, watertype and substrate on biomarker responses in the freshwater clam Corbicula fluminea (Müller). Comparative Biochemistry and Physiology Part C: Toxicology \& Pharmacology, 132(1), 93-104.

81. Vidal-Liñán, L., Bellas, J., Campillo, J.A., Beiras, R., 2010. Integrated use of antioxidant enzymes in mussels, Mytilus galloprovincialis, for monitoring pollution in highly productive coastal areas of Galicia (NW Spain). Chemosphere 78, 265-272. https://doi.org/10.1016/j.chemosphere.2009.10.060.

82. Vidal-Liñán, L., Bellas, J., Etxebarria, N., Nieto, O., Beiras, R., 2014. Glutathione S-transferase, glutathione peroxidase and acetylcholinesterase activities in mussels transplanted to harbour areas. Science of the total environment, 470, 107-116. https://doi.org/10.1016/j.scitotenv.2013.09.073.

83. Wepener, V., Bervoets, L., Mubiana, V., Blust, R., 2008. Metal exposure and biological responses in resident and transplanted blue mussels (Mytilus edulis) from the Scheldt estuary. Marine pollution bulletin, 57(6-12), 624-631. https://doi.org/10.1016/j.marpolbul.2008.03.030.

84. Whyte, J. J., Jung, R. E., Schmitt, C. J., Tillitt, D. E., 2000. Ethoxyresorufin-O-deethylase (EROD) activity in fish as a biomarker of chemical exposure. Critical reviews in toxicology, 30(4), 347-570. https://doi.org/10.1080/10408440091159239.

85. Wilhelm Filho, D., Tribess, T., Gaspari, C., Claudio, F. D., Torres, M. A., Magalhaes, A. R. M., 2001. Seasonal changes in antioxidant defences of the digestive gland of the brown mussel (Perna perna). Aquaculture, 203(1-2), 149-158. https://doi.org/10.1016/S0044-8486(01)00599-3.

86. Winston, G. W., Moore, M. N., Kirchin, M. A., Soverchia, C., 1996. Production of reactive oxygen species by hemocytes from the marine mussel, Mytilus edulis: lysosomal localization and effect of xenobiotics. Comparative Biochemistry and Physiology Part C: Pharmacology, Toxicology and Endocrinology, 113(2), 221-229. https://doi.org/10.1016/0742-8413(95)02091-8.

87. Zinkl, J. G., Lockhart, W. L., Kenny, S. A., Ward, F. J., 1991. The effects of cholinesterase inhibiting insecticides on fish. Cholinesterase-inhibiting insecticides, chemicals in agriculture, 2, 151Á.

\section{Figures}




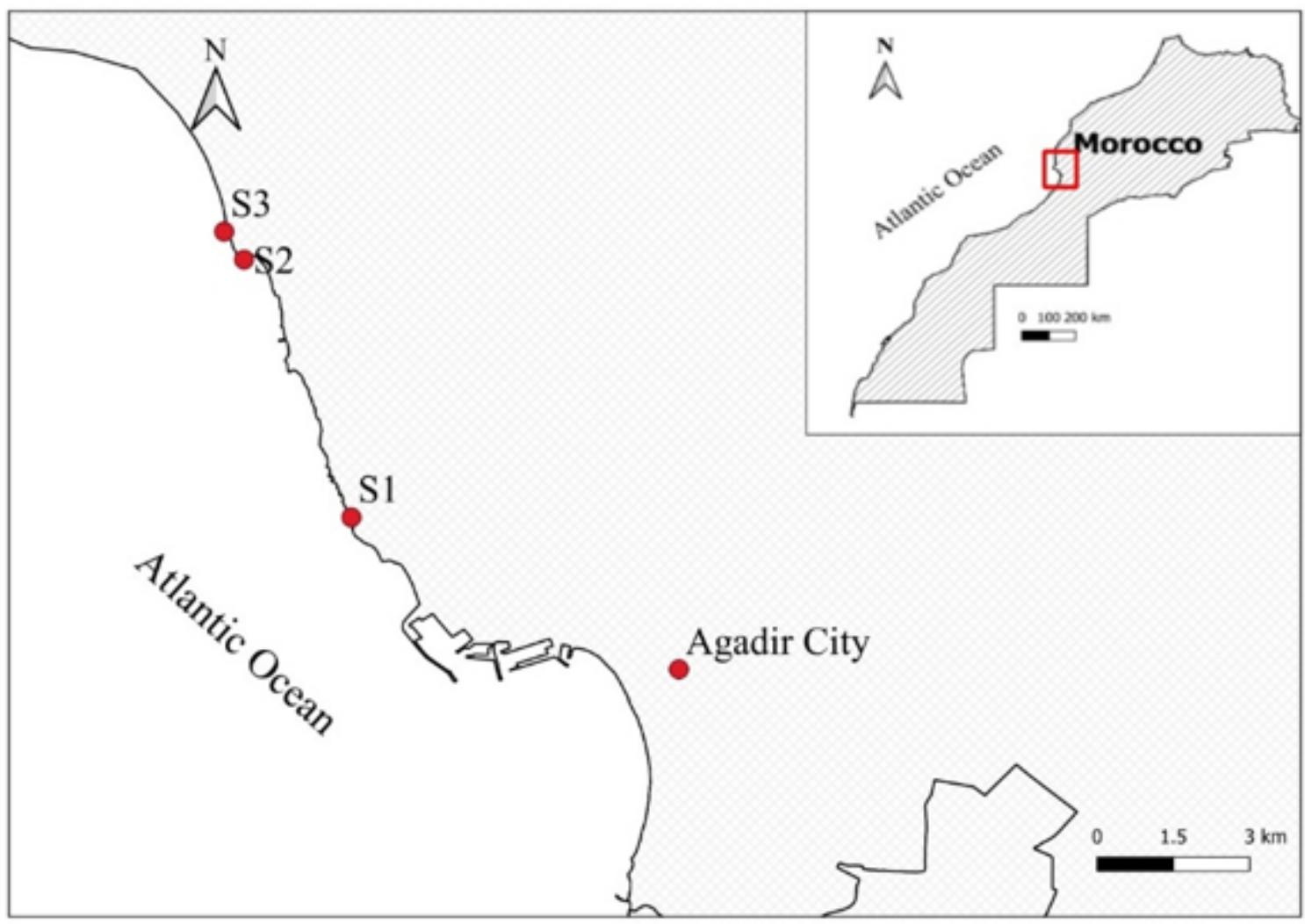

\section{Figure 1}

Location of the study area. S1) Anza beach. S2) Aourir beach. S3) Imouran beach. Note: The designations employed and the presentation of the material on this map do not imply the expression of any opinion whatsoever on the part of Research Square concerning the legal status of any country, territory, city or area or of its authorities, or concerning the delimitation of its frontiers or boundaries. This map has been provided by the authors. 

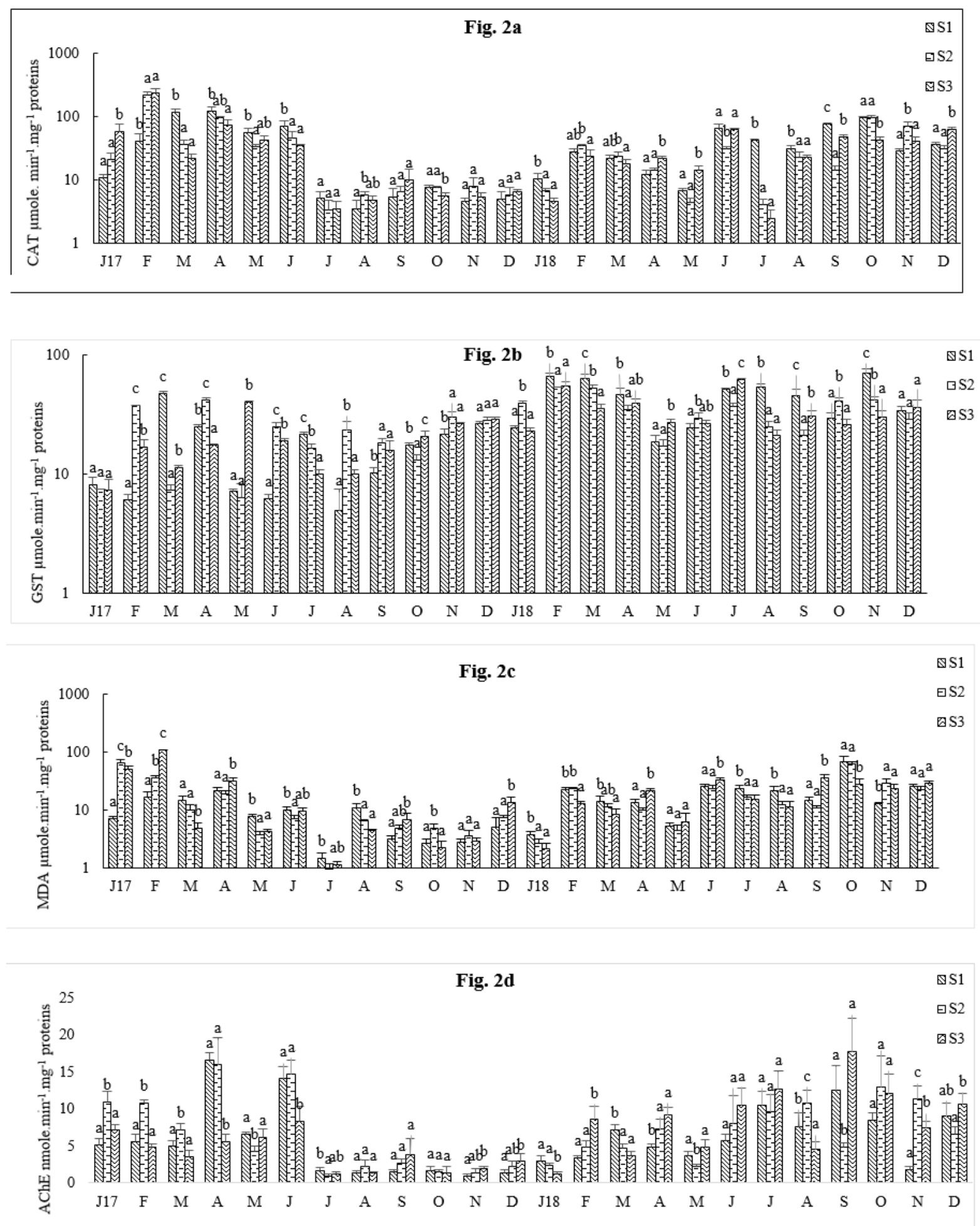

Figure 2

Mean enzymes levels of M. galloprovincialis in S9 of whole animal represented by site and months. a) Catalase activities, b) GST activities, c) MDA activities and d) AChE activities. The values indicate mean \pm SD, significant differences between sites were analysed by ANOVA (Tukey's post hoc test), groups with the same letters are not significantly different at the chosen level (5\%). 

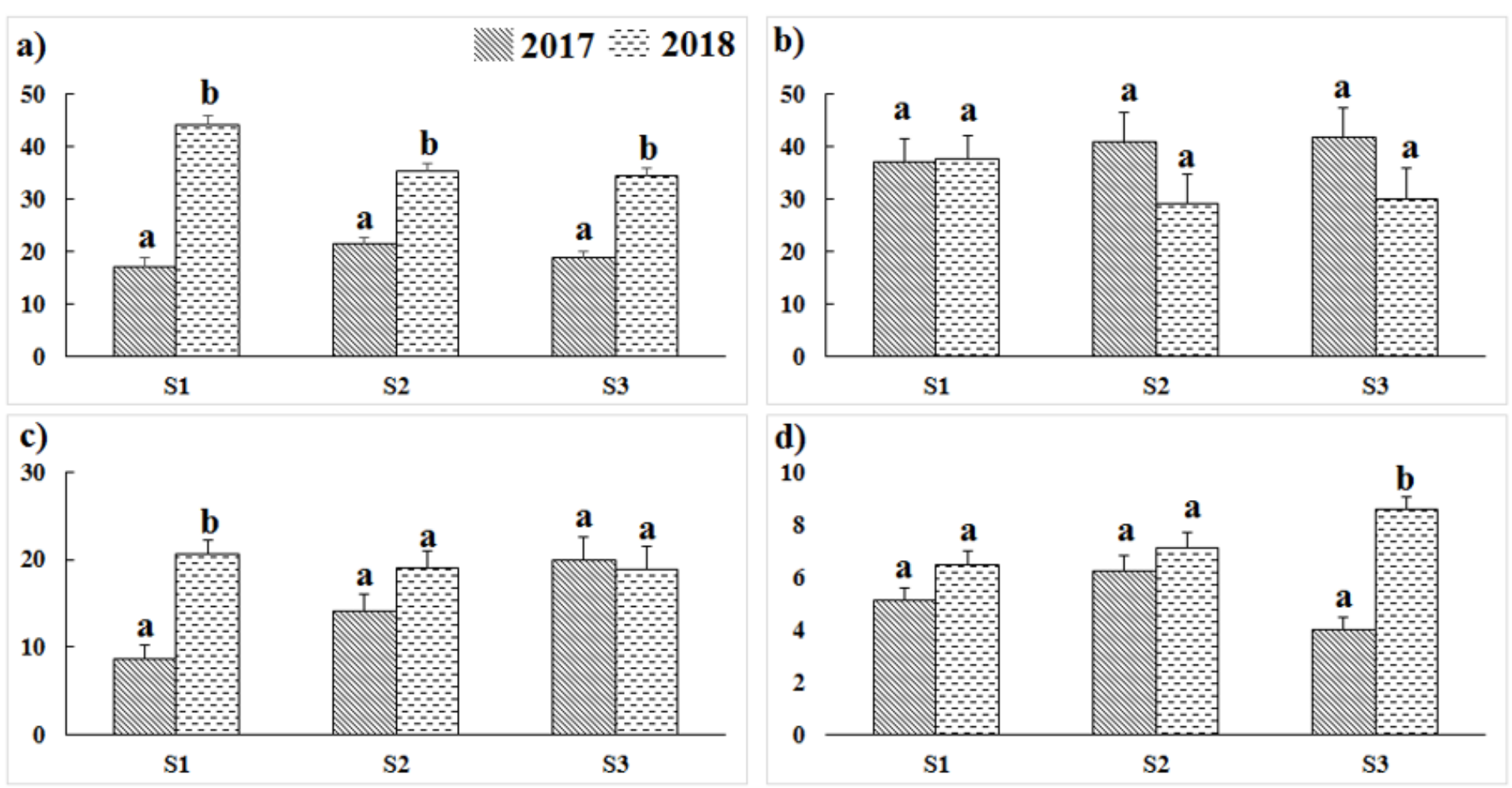

Figure 3

Annual Mean enzymes of Mytilus galloprovincialis in S9. a) GST activities, b) Catalase activities, c) MDA activities and d) AChE activities. The values indicate mean $\pm S E$, different letters mean significant differences at the chosen level (5\%). 


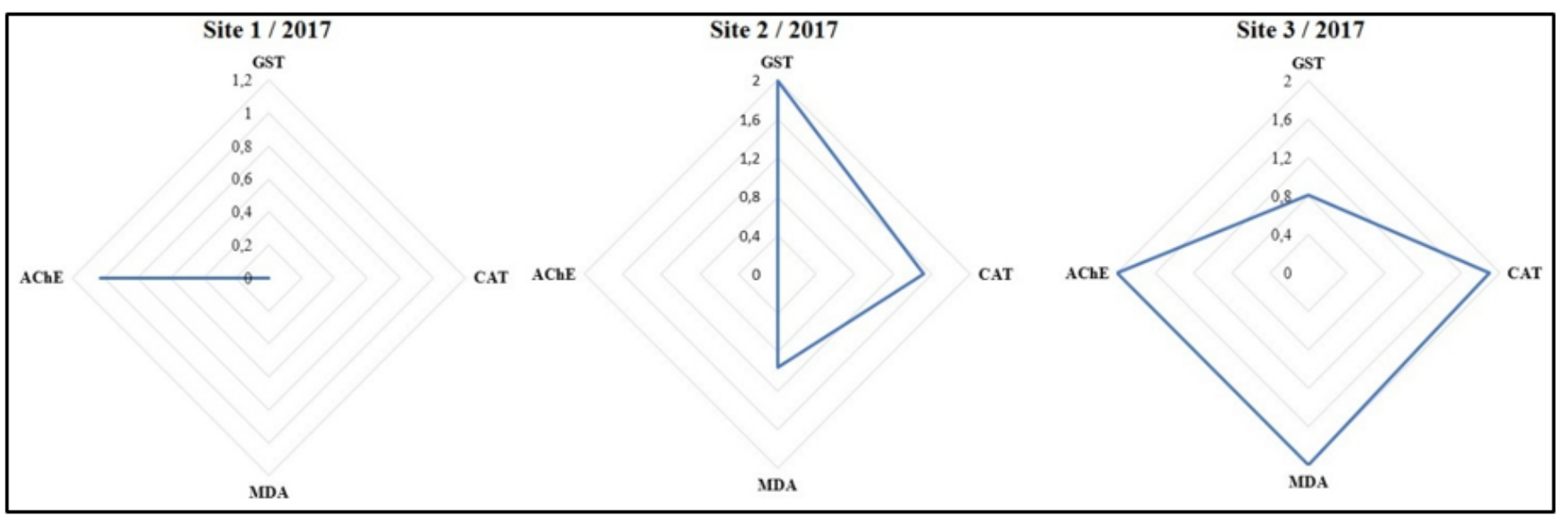

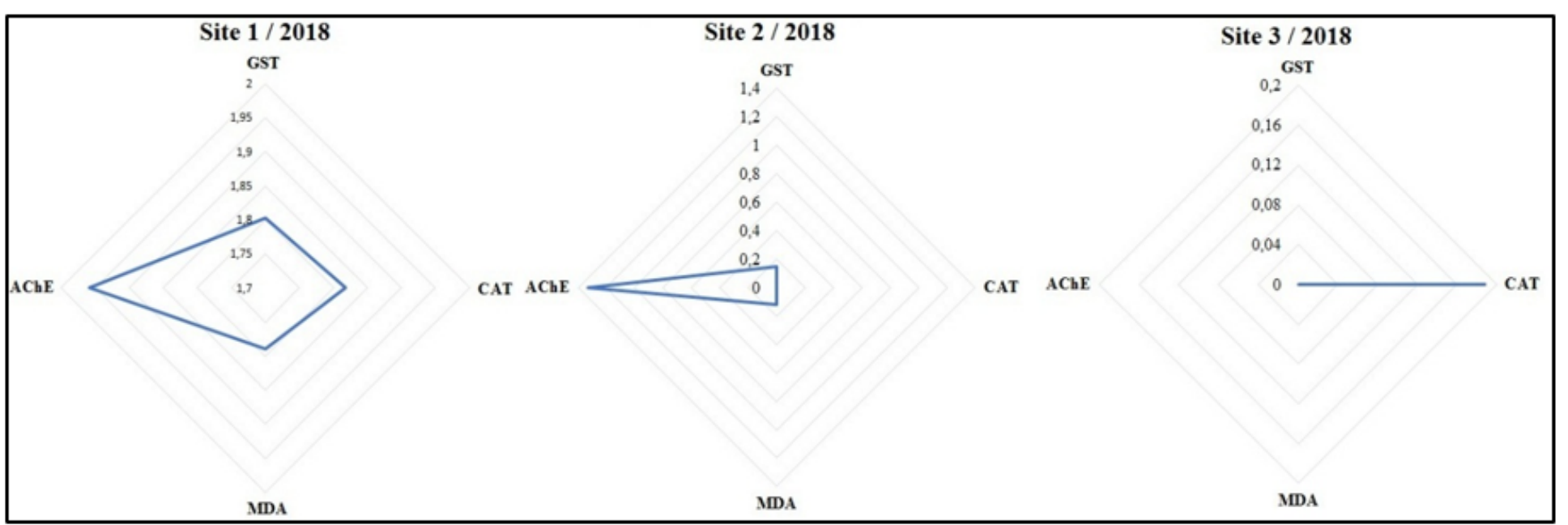

Figure 4

Radar graph of S1, S2 and S3 during 2017 and 2018 